\title{
Diagnoza klimatu społecznego młodzieżowych ośrodków wychowawczych w Polsce
}

\author{
Diagnosis of Social Climate \\ of Youth Delinquency Centers in Poland
}

\begin{abstract}
ABSTRAKT
Każda instytucja tworzy i charakteryzuje się swoistym klimatem, który może być sprzyjajqcy, pozytywny, korzystny, a nawet motywujqcy lub też niesprzyjajqcy, negatywny czy niewłaściwy. W artykule zaprezentowano problematykę zwiqzanq $z$ klimatem społecznym młodzieżowych ośrodków wychowawczych (MOW) w Polsce. Celem badań było poznanie opinii wychowanków i wychowawców na temat klimatu społecznego młodzieżowych ośrodków wychowawczych oraz zdiagnozowanie typu klimatu społecznego tych ośrodków w aspekcie relacji interpersonalnych, rozwoju osobistego i systemu organizacyjnego instytucji. Wykorzystano jako narzędzie badawcze Skalę Klimatu Społecznego Rudolfa H. Moosa. Analiza wyników badań pozwoliła na sformułowanie podstawowego wniosku, że w młodzieżowych ośrodkach wychowawczych dominuje niekorzystny dla procesu resocjalizacji nieletnich klimat społeczny. Kadra koncentruje się głównie na przestrzeganiu zewnętrznej dyscypliny i rygorów regulaminowych, w małym stopniu zwraca uwage na kształtowanie poprawnych stosunków interpersonalnych z wychowankami, a zupełnie zaniedbuje te elementy klimatu, które sprzyjają wytwarzaniu się terapeutycznego środowiska społeczności instytucjonalnej.
\end{abstract}

SLOWA KLUCZOWE klimat społeczny, nieletni, młodzieżowy ośrodek wychowawczy, wymiar Relacje interpersonalne, wymiar Rozwój osobisty, wymiar Orientacja praktyczna

\section{KEYWORDS}

social climate, juvenile, youth delinquency centers, Relationship dimension, Personal Development/Personal Growth dimension, Practical Orientation dimension

SPI Vol. 21, 2018/1 ISSN 2450-5358 e-ISSN 2450-5366 DOI: 10.12775/SPI.2018.1.008

Nadesłano: 6.12.2017 Zaakceptowano: 16.03.2018

Raporty z badań 


\section{ABSTRACT}

Each institution creates and is characterized by a specific atmosphere which may be favorable, beneficial, positive, perhaps even motivating, or, on the other hand, unfavorable, negative or improper. The article presents the issues related to the social climate of youth educational centers (YEC) in Poland. The purpose of the research was to recognize the wards' and educators' opinions on the social climate of the institutions, as well as diagnosing it in terms of interpersonal relations, personal development and organization. The Scale of Social Climate by Rudolf $\mathrm{H}$. Moos was used as a research tool. The analysis of the results led to a basic conclusion that an unfavorable climate prevails. The staff are focused mainly on extrinsic discipline and regulations, paying insufficient attention to proper interpersonal relations with their wards. Therapeutic aspects of the social climate are largely neglected.

\section{Wprowadzenie}

Klimat społeczny panujący w danej instytucji jest pojęciem bardzo szerokim, które może być używane w różnych aspektach. Przy definiowaniu klimatu danej instytucji często używa się takich pojęć jak: atmosfera, nastrój, zbiór wartości, norm i poglądów, subiektywny obraz zjawisk, osobowość instytucji, coś, co tworzy warunki sprzyjające pewnym postawom i wzorcom zachowań, zbiór cech organizacji czy też zachowania będące funkcją osobowości i środowiska. Pojęcia klimatu używa się zwłaszcza jako kategorii diagnozującej lub diagnozująco-opisowej w badaniach nad efektywnością organizacji czy zespołów badawczych ${ }^{1}$.

$\mathrm{W}$ opisie pojęcia klimatu może się też pojawić sformułowanie „typ klimatu”, które zostaje użyte jako kategoria opisująca wyniki jego badania. Klimat może zostać scharakteryzowany przez takie określenia jak np. klimat terapeutyczny, wychowawczy, opiekuńczy, kontrolujący, restrykcyjny oraz przez konfiguracje typów, np.

1 Por. B. Adrjan, Klimat szkoty, w: Encyklopedia pedagogiczna XXI wieku, t. 2, red. T. Pilch, Warszawa 2008, s. 610. 
kontrolująco-restrykcyjny ${ }^{2}$. W opisie badań można zdiagnozować klimat jako: sprzyjający, niesprzyjający ${ }^{3}$, wspierający, twórczy, proinnowacyjny, zaangażowany, korzystny ${ }^{4}$, pozytywny, negatywny, właściwy, niewłaściwy, otwarty, zamknięty - jako końcowe punkty kontinuum możliwego klimatu 5 .

W naukach społecznych występuje pojęcie klimatu społecznego (social climate) w kontekście instytucji lub klimatu organizacyjnego. Psychologia posługuje się natomiast np. pojęciem klimatu emocjonalnego.

W odniesieniu do zjawisk psychospołecznych pojęcia klimatu jako pierwszy użył Kurt Lewin ${ }^{6}$, definiując go jako funkcję osobowości i środowiska. Wskazał na istotne znaczenie relacji między osobą $\mathrm{i}$ instytucją. Wypadkową tej relacji są zachowania pojedynczych osób, które tworzą klimat instytucji. W pojęcie klimatu jest wpisana jednocześnie atrybucja subiektywności, gdyż klimat stanowi wypadkową subiektywnych odczuć uczestników organizacji, dotyczących obiektywnie istniejącej rzeczywistości ${ }^{7}$. Może więc mieć miejsce sytuacja, że różni członkowie grupy lub instytucji będą mieli odmienny obraz klimatu w niej panującego ${ }^{8}$.

Zdaniem Rudolfa H. Moosa, klimat społeczny jest swego rodzaju „osobowością” otoczenia lub środowiska ${ }^{9}$. Każde społeczne otoczenie

2 Por. L. Pytka, Pedagogika resocjalizacyjna. Wybrane zagadnienia teoretyczne, diagnostyczne i metodyczne, Warszawa 2005.

3 Por. J. Tatarowicz, Klimat spoteczny szkoty - zdrowy czy chory?, w: Zanim w szkole będzie źle... Profilaktyka zagrożeń, red. K. Ostrowska, J. Tatarowicz, Warszawa 1996.

4 Por. I. Pufal-Struzik, Atmosfera i klimat organizacji jako czynniki stymulujace lub hamujące efektywnośc twórczych zachowań pracowników, w: Myśl psychologiczna w Polsce Odrodzonej, red. A. Bańka, R. Derbis, Poznań 1993.

5 Por.W.K. Hoy,J.W. Hanuum, Middle School Climate: An Empirical Assessment of Organizational Health and Student Achievement, „Educational Administration Quarterly"1998, t. 33, nr 3, s. 290-301.

6 Por. K. Lewin, Field theory in social science: Selected theoretical papers, Washington (DC) 1951.

7 Por. M. Bratnicki, M. Wyciślak, Klimat organizacyjny: pojęcie, mierzenie, badania i diagnoza, „Prakseologia” 1980, nr 4(76), s. 93.

8 Por. B. Adrjan, Klimat szkoty, dz. cyt., s. 610.

9 Por. R.H. Moos, The Social Climate Scales: A User's Guide, Menlo Park (CA) 1994, s. 1. 
ma niepowtarzalną „osobowość”, która nadaje temu otoczeniu jedność i spójność. Niektóre środowiska społeczne, podobnie jak ludzie, są bardziej przyjazne i wspierające niż inne, zorientowane na zadania lub samokierujące. Różnią się także poziomem restrykcyjności i kontrolowania. Klimat społeczny może mieć silny wpływ na ludzi w otoczeniu. Badania wykazały, że klimat społeczny wpływa na zachowanie każdej osoby, na jej uczucia i przystosowanie. Szczególnie klimat społeczny może mieć wpływ na morale jednostki i jej poczucie zadowolenia, aspiracje, osiagnięcia, poczucie samozrozumienia oraz kontroli impulsów itp. Według Lesława Pytki,

[...] klimat społeczny instytucjonalnego środowiska wychowawczego to zbiór subiektywnie postrzeganych przez wychowanków oraz wychowawców charakterystycznych cech, sytuacji, zdarzeń, będących względnie trwałymi skutkami jego funkcjonowania $\mathrm{w}$ ramach przyjętego systemu organizacyjnego i pedagogicznego, kształtujący motywacje i zachowania jednostek i grup społecznych tej instytucji ${ }^{10}$.

Ponadto członkowie tej instytucji wierzą, iż rzeczywiście on istnieje. Justyna Siemionow ${ }^{11}$ używa pojęcia „wewnętrzny klimat instytucji”. Może on sprzyjać osiągnięciu określonych efektów podejmowanych działań resocjalizacyjnych lub też być istotną barierą i przeszkodą. Na klimat instytucji resocjalizacyjnej składają się: poczucie bezpieczeństwa, relacje wychowawca-wychowanek, relacje między wychowankami, dbałość o integrację wewnątrz grup oraz podmiotowe, indywidualne traktowanie. Również na klimat instytucji wpływają relacje między wychowankami a poszczególnymi pracownikami zatrudnionymi w placówce (kadra pedagogiczna, dyrekcja, personel obsługowy), sposób wzajemnej komunikacji, jakość tych kontaktów, ich budowanie i podtrzymywanie.

Zdaniem Marka Konopczyńskiego ${ }^{12}$, klimat społeczny w kontekście twórczej resocjalizacji rozumiany jest jako sumujący się wobec

10 L. Pytka, Pedagogika resocjalizacyjna. Wybrane zagadnienia teoretyczne, diagnostyczne i metodyczne, dz. cyt., s. 164.

11 Por. J. Siemionow, Efektywność oddziatywań instytucji resocjalizacyjnych a nowe trendy w resocjalizacji, w: Wspótczesne kierunki zmian w teorii i praktyce resocjalizacyjnej, red. M. Konopczyński, W. Ambrozik, Warszawa 2009, s. 95-96.

12 Por. M. Konopczyński, Teoretyczne podstawy metodyki kulturotechnicznych oddziatywań resocjalizacyjnych wobec nieletnich. Zarys koncepcji twórczej resocjalizacji, Warszawa 2006, s. 136. 
zamierzeń i działań zbiór postaw osób z najbliższego kręgu społecznego; zaliczyć tu można zarówno wychowawców, specjalistów, wychowanków, jak i cały personel administracyjno-gospodarczy placówki. Odpowiednio wytworzony wokół realizowanych metod klimat społeczny może działać motywująco na uczestników oraz kształtować ich nową, zewnętrzną ocenę społeczną, a przez to zmieniać ich wizerunek wewnętrzny. Klimat o zabarwieniu negatywnym lub postrzegany jako negatywny może obniżać motywację do uczestnictwa w działaniach, a nawet prowadzić do podjęcia decyzji o rezygnacji z zajęć.

W każdej z przytoczonych definicji można odnaleźć inny aspekt. Jednakże ich autorzy często wskazują na dwa elementy: na działania i zachowania każdego członka danej zbiorowości instytucjonalnej oraz nawiązanie do instytucji jako pewnego rodzaju „systemu”, który ma wpływ na zachowania jej członków poprzez kształtowanie sprzyjającego lub niesprzyjającego klimatu wychowawczego.

Rudolf H. Moos ${ }^{13}$, w oparciu o koncepcje Henry'ego Murraya oraz George'a Sterna, dokonał analizy społecznego środowiska różnych instytucji. W jej wyniku wyodrębnił różne czynniki, które tworzą wymiary klimatu społecznego danej instytucji. Czynniki te różnią się w zależności od instytucji (potrzeb i celów, zarówno podopiecznych, jak i kadry), jednak można je pogrupować w trzy wymiary: relacje interpersonalne w obrębie instytucji, rozwój osobisty podopiecznych instytucji, system organizacyjny instytucji.

W oparciu o koncepcję Rudolfa H. Moosa oraz na podstawie przeprowadzonych badań, Lesław Pytka dokonał charakterystyki i podziału klimatu społecznego w polskich instytucjach dla nieletnich na:

1. Terapeutyczno-wychowawczy - koncentruje się na kształtowaniu przyjaznych stosunków interpersonalnych o wyraźnym zabarwieniu terapeutycznym, gdzie funkcje kontrolno-represyjne zostały zredukowane do minimum. Jest to najbardziej sprzyjający typ klimatu społecznego, w którym model resocjalizacji, wychowania oraz opieki powinien być realizowany.

2. Opiekuńczo-wychowawczy - jest również pożądanym typem klimatu, gdyż koncentruje się przede wszystkim

13 Por. R.H. Moos, Evaluating correctional and community settings, New York London - Sydney - Toronto 1975, s. 19-25. 
na zaspokajaniu potrzeb wychowanków. Na drugim miejscu uwidaczniają się jako ważne parametry organizacyjne instytucji.

3. Kontrolująco-opiekuńczy - świadczy już o niekorzystnych tendencjach $\mathrm{w}$ organizowaniu środowiska wychowawczego, gdyż największy nacisk kładziony jest na kontrolę zachowania wychowanków i ład wewnątrzinstytucjonalny, mniejszy zaś na przygotowanie praktyczne wychowanków, a jeszcze mniejszy na kształtowanie niekonfliktowych stosunków interpersonalnych.

4. Kontrolująco-restrykcyjny - jest najbardziej niepożądanym klimatem społecznym, ponieważ koncentruje się on głównie na przestrzeganiu zewnętrznej dyscypliny i rygorów regulaminowych. W małym stopniu zwraca się uwagę na kształtowanie poprawnych stosunków interpersonalnych, a zupełnie zaniedbuje się te elementy klimatu, które sprzyjają wytwarzaniu się terapeutycznego środowiska społeczności instytucjonalnej ${ }^{14}$.

Klimat społeczny instytucji jest brany pod uwage wraz z innymi czynnikami w kontekście oceny efektywności procesu wychowania. Miarą skuteczności wychowawczej jest poziom zaspokojenia potrzeb psychicznych, internalizacja przez wychowanków właściwych wartości i postaw społecznych oraz mechanizmów kontroli wewnętrznej, a także ukształtowanie odpowiednich ról społecznych oraz przygotowanie wychowanków do samodzielnego i twórczego funkcjonowania w społeczeństwie ${ }^{15}$.

\section{Badania własne ${ }^{16}$}

Przedmiotem badań były opinie wychowanków młodzieżowych ośrodków wychowawczych $(\mathrm{MOW})^{17}$ i zatrudnionej w nich kadry

14 Por. L. Pytka, Pedagogika resocjalizacyjna. Wybrane zagadnienia teoretyczne, diagnostyczne i metodyczne, dz. cyt.

15 Tamże, s. 165-166.

16 Prezentowane przez autorkę wyniki badań stanowią fragment większych badań nad klimatem społecznym młodzieżowych ośrodków wychowawczych zaprezentowanych $\mathrm{w}$ niepublikowanej rozprawie doktorskiej pt. Klimat spoteczny mtodzieżowych ośrodków wychowawczych w Polsce. Studium resocjalizacyjne (Uniwersytet Łódzki, 2015).

17 Zamiennie jest używana nazwa Ośrodek lub MOW na określenie młodzieżowego ośrodka wychowawczego. 
na temat klimatu społecznego młodzieżowych ośrodków wychowawczych w Polsce.

Celem badań była natomiast próba postawienia diagnozy klimatu społecznego młodzieżowych ośrodków wychowawczych w Polsce i na tej podstawie dokonanie klasyfikacji stwierdzonych empirycznie typów klimatu społecznego.

Podstawowy problem badawczy można było więc wyrazić w pytaniu: Jaki klimat społeczny dominuje w młodzieżowych ośrodkach wychowawczych w Polsce w opinii wychowanków przebywających w Ośrodkach i zatrudnionej tam kadry?

Problem badawczy został sformułowany bardzo ogólnie, dlatego wymagał uszczegółowienia poprzez postawienie dodatkowych pytań badawczych:

1. Jak kształtuje się klimat społeczny MOW w zakresie relacji interpersonalnych w opinii wychowanków przebywających w ośrodkach i zatrudnionej tam kadry?

2. Jak kształtuje się klimat społeczny MOW w zakresie rozwoju osobistego w opinii wychowanków przebywających w Ośrodkach i zatrudnionej tam kadry?

3. Jak kształtuje się klimat społeczny MOW w zakresie systemu organizacyjnego w opinii wychowanków przebywających w Ośrodkach i zatrudnionej tam kadry?

W badaniach wykorzystano jako narzędzie badawcze Skalę Klimatu Społecznego (Correctional Institutions Environment Scale CIES), autorstwa Rudolfa H. Moosa, w wersji „Form R”, która mierzy aktualne środowisko społeczne instytucji w percepcji osób badanych. Skala ta należy do grupy skal dotyczących klimatu społecznego (The Social Climate Scales) opracowanych przez Moosa ${ }^{18}$ i jest wystandaryzowanym narzędziem badawczym, adaptowanym zgodnie z normami do polskich warunków przez Lesława Pytkę ${ }^{19}$. Jest ona przeznaczona do pomiaru klimatu społecznego instytucji i środowisk wychowawczych zakładowych placówek wychowawczych.

18 Por.: R.H. Moos, Evaluating correctional and community settings, dz. cyt.; R.H. Moos, Correctional Institutions Environment Scale: Sampler Set, Menlo Park (CA) 1974; R.H. Moos, The Social Climate Scales: A User's Guide, dz.cyt.

19 Por. L. Pytka, Pedagogika resocjalizacyjna. Wybrane zagadnienia teoretyczne, diagnostyczne i metodyczne, dz. cyt., s. 167-173. 
Skala Klimatu Społecznego ${ }^{20}$ składa się z dziewięciu podskal, które tworzą trzy wymiary:

Pierwszy wymiar - Relacje interpersonalne (Relationship dimension $)^{21}$ :

1. Zaangażowanie (Involvement) - mierzy stopień zaangażowania w wykonywanie codziennych zadań i obowiązków, wykazywanie inicjatywy, np. w relacjach społecznych;

2. Wsparcie (Support $)^{22}$ - określa, w jakim stopniu podopieczni są zachęcani do pomocy wobec innych podopiecznych oraz jak personel wspiera podopiecznych;

3. Ekspresja (Expressiveness) - mierzy stopień, w jakim podopieczni oraz personel mogą otwarcie wyrażać swoje uczucia, w tym również uczucie złości.

Drugi wymiar - Rozwój osobisty (PersonalDevelopment) Personal Growth dimension):

1. Autonomia (Autonomy) - pozwala ocenić, w jakim stopniu podopieczni są zachęcani do podejmowania inicjatywy w planowaniu działań oraz objęciu kierownictwa (leadership);

2. Orientacja praktyczna (Practical Orientation) - pozwala ocenić zakres, w jakim podopieczni są przygotowywani do opuszczenia instytucji, np. udział w szkoleniach celem zdobycia nowego zawodu. Lesław Pytka wskazuje, że podskala ta również służy do oceny działalności instytucji w zakresie rozwiązywania problemów praktycznych wychowanka, np. związanych z nauką szkolną czy przygotowaniem zawodowym, a także z przygotowaniem do samodzielnego życia w społeczeństwie ${ }^{23}$;

3. Orientacja na problemy osobiste (Personal Problem Orientation) mierzy, w jakim stopniu podopieczni są zachęcani do dokonywania „wglądu w siebie”, do „przyglądania się" własnym problemom osobistym i uczuciom celem zrozumienia ich.

20 R.H. Moos, Evaluating correctional and community settings, dz. cyt., s. 16-53; L. Pytka, Pedagogika resocjalizacyjna. Wybrane zagadnienia teoretyczne, diagnostyczne i metodyczne, dz. cyt., s. 168-170.

21 Nazwy zostały przejęte $\mathrm{z}$ oryginalnej wersji Skali, stąd czasami występują różnice między nazwami przyjętymi w polskiej adaptacji Skali. Lesław Pytka używa nazwy Stosunki interpersonalne.

22 Lesław Pytka używa nazwy Podtrzymywanie.

23 Por. L. Pytka, Pedagogika resocjalizacyjna. Wybrane zagadnienia teoretyczne, diagnostyczne i metodyczne, dz. cyt., s. 168. 
Trzeci wymiar - System organizacyjny (System Maintenance and/or System Change dimension):

1. Porządek i organizacja (Order and Organization) - pozwala na określenie stopnia utrzymania porządku i dobrej organizacji instytucji oraz przestrzegania przez podopiecznych dyscypliny;

2. Jasność/Klarowność (Clarity) ${ }^{24}$ - mierzy stopień znajomości przez podopiecznego zasad i procedur panujących w instytucji oraz znajomości codziennych, rutynowych zadań;

3. Kontrola personelu (Staff Control) $)^{25}$ - ocenia, w jakim stopniu personel wykorzystuje przepisy obowiązujące $w$ instytucji, celem utrzymania podopiecznych $\mathrm{w}$ ramach niezbędnej kontroli (tj. poprzez formułowanie zasad, planowanie działań oraz stosunki między podopiecznymi a personelem).

Rezultatem przeprowadzonych badań są uzyskiwane średnie arytmetyczne w zakresie poszczególnych podskal. Dzięki statystycznemu opracowaniu wyników można dokonać oszacowania jakości społecznego klimatu instytucjonalnego środowiska wychowawczego. Im większe występują rozbieżności w ocenie dokonywanej, np. przez podopiecznych i personel, tym mniejsze prawdopodobieństwo występowania sprzyjającego wychowawczo klimatu społecznego badanej instytucji ${ }^{26}$.

$\mathrm{Z}$ uwagi na przedmiot i cel badań, dobrano taką liczbę Ośrodków, która stanowiłaby około $28 \%$ wszystkich młodzieżowych ośrodków wychowawczych w Polsce, uwzględniając wielkość placówki, miejsce położenia, płeć wychowanków (MOW dla dziewcząt, MOW dla chłopców oraz MOW koedukacyjny) oraz organ prowadzący placówkę. Wylosowano $19 \mathrm{MOW}$ o typie resocjalizacyjnym ${ }^{27}$.

Wśród wytypowanych do badań MOW przeważały średnie (9), następnie duże (6) i małe (4); najczęściej były one usytuowane na terenach wiejskich (10), dalej - w małych miastach (4), w dużych

24 Lesław Pytka używa nazwy Jasność celów, zadań, regulaminów.

25 Lesław Pytka używa nazwy Kontrola wychowawcza.

26 Por. R.H. Moos, Correctional Institutions Environment Scale: Sampler Set, dz. cyt., s. 11; L. Pytka, Pedagogika resocjalizacyjna. Wybrane zagadnienia teoretyczne, diagnostyczne i metodyczne, dz. cyt., s. 170.

27 Rozporządzenie Ministra Edukacji Narodowej z dnia 2 listopada 2015 roku w sprawie rodzajów i szczegółowych zasad działania placówek publicznych, warunków pobytu dzieci i młodzieży w tych placówkach oraz wysokości i zasad odpłatności wnoszonej przez rodziców za pobyt ich dzieci w tych placówkach (Dz.U. z 2015 r. Nr 0, poz. 1872). 
miastach (3), w średnich miastach (2). Większość Ośrodków była prowadzona przez samorządy (15), po jednym przez instytucję kościelną, organizację pozarządową, osobę fizyczną i firmę.

W badanych Ośrodkach było łącznie 1214 miejsc, z czego 824 miejsc dla chłopców, 162 miejsca dla dziewcząt oraz 228 miejsc w Ośrodkach koedukacyjnych. W badaniach uczestniczyło 673 wychowanków ${ }^{28}$.

Łącznie badaniami objęto 940 osób, w tym: 673 wychowanków (457 chłopców, 216 dziewcząt), 249 osób z personelu zatrudnionego w Ośrodkach (104 mężczyzn, 145 kobiet).

Poniżej przedstawiono analizę wyników badań dotyczących klimatu społecznego w MOW w percepcji wychowanków i kadry w zakresie relacji interpersonalnych, rozwoju osobistego wychowanków oraz systemu organizacyjnego Ośrodka.

$Z$ analizy w zakresie wymiaru Relacje interpersonalne wynika, że średnie dla podskal „Zaangażowanie”, „Wsparcie” i „Ekspresja”, uzyskane przez wychowanków oraz kadrę zatrudnioną w MOW, różnią się w sposób istotny statystycznie (Tabela 1).

Tabela 1. Porównanie wyników w zakresie wymiaru Relacje interpersonalne, uzyskanych przez wychowanków MOW i kadrę pracująca w MOW

\begin{tabular}{|l|c|c|c|c|c|}
\hline \multirow{2}{*}{$\begin{array}{c}\text { Wymiar pierwszy: } \\
\text { Relacje } \\
\text { interpersonalne }\end{array}$} & \multicolumn{2}{|c|}{ Wychowankowie (N=616) } & \multicolumn{2}{|c|}{ Kadra (N=230) $)^{30}$} & \multirow{2}{*}{$\begin{array}{c}\text { p w teście } \\
\text { t-Studenta }\end{array}$} \\
\cline { 2 - 5 } & $\bar{\chi}$ & SD & $\bar{\chi}$ & SD & \\
\hline Zaangażowanie & 6,66 & 2,394 & 8,32 & 1,616 & $<0,0005$ \\
\hline Wsparcie & 6,65 & 2,610 & 8,82 & 1,178 & $<0,0005$ \\
\hline Ekspresja & 4,77 & 1,684 & 6,05 & 1,689 & $<0,0005$ \\
\hline
\end{tabular}

Źródło: badania własne.

28 Rozbieżność między liczbą miejsc dla wychowanków a liczbą osób objętych badaniami wynikała przede wszystkim $\mathrm{z}$ faktu, że część wychowanków przebywała na praktykach zawodowych lub „na ucieczce”.

29 Badaniami objęto 673 wychowanków, natomiast prawidłowo SKS wypełniło 616 wychowanków.

30 Badaniami objęto 249 osób z kadry, natomiast prawidłowo SKS wypełniło 230 osób. 
W podskali „Zaangażowanie” kadra zatrudniona w MOW wyżej ocenia własne zaangażowanie w codzienną realizację zadań własnych, jak i wychowanków. Wykazuje również więcej inicjatywy $\mathrm{w}$ relacjach $\mathrm{z}$ wychowankami. Wychowankowie zaś uważają, że kadra jest słabo zaangażowana w wypełnianie swoich zadań i obowiązków.

W podskali „Wsparcie” kadra zdecydowanie mocniej (niż wyrażają to wychowankowie) deklaruje chęć udzielania im wsparcia emocjonalnego oraz pomocy. Jak również mocniej zachęca wychowanków do pomagania innym rówieśnikom, niż oceniają to wychowankowie. W tej podskali występuje największa rozbieżność średnich arytmetycznych wyników uzyskanych przez wychowanków i kadrę.

W podskali „Ekspresja”, zdaniem kadry, zarówno pracownicy, jak i wychowankowie przebywający w Ośrodku, mogą w sposób otwarty wyrażać swoje opinie, uczucia. Natomiast wychowankowie twierdzą, że nie mogą szczerze i otwarcie okazywać swoich uczuć oraz różnorodnych emocji, zwłaszcza złości, a także wypowiadać swojego zdania na temat Ośrodka, zasad i reguł, jakie w nim panują. Niemożność wyrażania własnych opinii oraz uczuć, a także ścisła samokontrola ich zachowania (np. zachowań niepożądanych, agresywnych), sprzyjają powstawaniu tzw. „drugiego życia” w Ośrodku ${ }^{31}$.

Jak wynika $\mathrm{z}$ analizy powyższych podskal tworzących wymiar Relacje interpersonalne, klimat społeczny MOW nie kształtuje się prawidłowo i nie sprzyja budowaniu pozytywnych relacji interpersonalnych pomiędzy wychowankami a kadrą zatrudnioną w Ośrodkach.

Z analizy w zakresie wymiaru Rozwój osobisty wynika, że średnie dla podskal Autonomia, Orientacja praktyczna, Orientacja na problemy osobiste, uzyskane przez wychowanków oraz kadrę zatrudnioną w MOW, różnią się w sposób istotny statystycznie (Tabela 2).

31 Por. M. Kuć, Prawne podstawy resocjalizacji, Warszawa 2011. 
Tabela 2. Porównanie wyników w zakresie wymiaru Rozwój osobisty uzyskanych przez wychowanków MOW i kadrę pracująca w MOW

\begin{tabular}{|l|c|c|c|c|c|}
\hline \multirow{2}{*}{$\begin{array}{c}\text { Wymiar drugi: } \\
\text { Rozwój osobisty }\end{array}$} & \multicolumn{2}{|c|}{ Wychowankowie (N=616) } & \multicolumn{2}{|c|}{ Kadra (N=230) } & \multirow{2}{*}{$\begin{array}{c}\text { p w teście } \\
\text { t-Studenta }\end{array}$} \\
\cline { 2 - 6 } & $\bar{\chi}$ & SD & $\bar{\chi}$ & SD & \\
\hline Autonomia & 5,73 & 1,746 & 6,49 & 1,163 & $<0,0005$ \\
\hline Orientacja praktyczna & 5,66 & 1,828 & 7,90 & 1,298 & $<0,0005$ \\
\hline $\begin{array}{l}\text { Orientacja na problemy } \\
\text { osobiste }\end{array}$ & 5,70 & 1,915 & 7,67 & 1,123 & $<0,0005$ \\
\hline
\end{tabular}

Źródło: badania własne.

W podskali „Autonomia” wychowankowie uważają, że nie mają wpływu na zasady, jakie panują w Ośrodku, a regulamin bardzo ściśle określa ich prawa i obowiązki. Również nie mają wpływu na decyzje ich dotyczące, gdyż te są podejmowane głównie przez dyrekcję oraz kadrę pedagogiczną/wychowawców. Również kadra uważa, że decyzje dotyczące wychowanków są podejmowane przez dyrekcję i kadrę. Decyzje te są najczęściej podejmowane jako odgórne polecenia dyrekcji i kadry, na które wychowankowie nie mają wpływu. Taka postawa dyrekcji i kadry nie sprzyja rozwijaniu niezależności wychowanków oraz przejmowaniu przez nich inicjatywy w zakresie funkcjonowania w MOW i planowania przyszłego życia. Bardziej sprzyja to kreowaniu postawy konformistycznej u wychowanków oraz powstawaniu u nich wyuczonej bezradności ${ }^{32}$.

W podskali „Orientacja praktyczna” kadra uważa, że w odpowiedni sposób angażuje się w rozwiązywanie problemów swoich wychowanków. Innego zdania są wychowankowie. Twierdzą oni, że kadra w zbyt małym zakresie pomaga im w kwestiach nauki czy też przygotowania do opuszczenia placówki. Taka rozbieżność może wynikać z przyjętej przez wychowanków postawy roszczeniowej, którzy często uważają, że proponowane im zajęcia są nieadekwatne do ich zainteresowań i mało praktyczne.

W podskali „Orientacja na problemy osobiste” wychowankowie uważają, że rzadko są zachęcani do autorefleksji na temat własnych emocji czy zachowań, mają mniejszy „wgląd w siebie”. Taka sytuacja

32 Por. M. Seligman, Optymizmu można się nauczyć. Jak zmienić swoje myślenie i swoje życie, przeł. A. Jankowski, Poznań 2007. 
może mieć miejsce dlatego, że w Ośrodkach rzadko prowadzona jest terapia indywidualna, dzięki której wychowankowie mogliby się nauczyć wyrażania czy też kontroli własnych emocji. Socjoterapia, która jest obowiązkowo prowadzona w MOW, ma status zajęć lekcyjnych, więc nie spełnia swojej funkcji w sposób właściwy.

Jak wskazuje analiza powyższych podskal tworzących wymiar Rozwój osobisty, klimat społeczny MOW w tym zakresie nie kształtuje się prawidłowo, a kadra zatrudniona w Ośrodkach nie zaspokaja w sposób właściwy potrzeb wychowanków, np. w zakresie ich autonomii, samodzielności, samopoznania itp.

$\mathrm{Z}$ analizy wymiaru Rozwój osobisty wynika, że średnie dla podskal „Porządek i organizacja”, „Jasność/Klarowność”, uzyskane przez wychowanków oraz kadrę zatrudnioną w MOW, różnią się w sposób istotny statystycznie. Natomiast średnia dla wychowanków i średnia dla kadry w podskali „Kontrola personelu” nie różnią się w sposób istotny (Tabela 3).

Tabela 3. Porównanie wyników w zakresie wymiaru System organizacyiny uzyskanych przez wychowanków MOW i kadrę pracująca w MOW

\begin{tabular}{|l|c|c|c|c|c|}
\hline \multirow{2}{*}{$\begin{array}{c}\text { Wymiar trzeci: } \\
\text { System organizacyiny }\end{array}$} & \multicolumn{2}{|c|}{$\begin{array}{c}\text { Wychowankowie } \\
\text { (N=616) }\end{array}$} & \multicolumn{2}{c|}{ Kadra (N=230) } & \multirow{2}{*}{$\begin{array}{c}\text { P w teście } \\
\text { t-Studenta }\end{array}$} \\
\cline { 2 - 6 } & $\bar{\chi}$ & SD & $\bar{\chi}$ & SD & \\
\hline Porzqqdek i organizacja & 6,53 & 2,040 & 8,00 & 1,420 & $<0,0005$ \\
\hline Jasność/Klarowność & 6,01 & 1,688 & 6,96 & 1,260 & $<0,0005$ \\
\hline Kontrola personelu & 5,88 & 1,556 & 5,96 & 1,489 & 0,519 \\
\hline
\end{tabular}

Źródło: badania własne.

Analiza wyników uzyskanych przez kadrę zatrudnioną w Ośrodkach dla podskali „Porządek i organizacja” świadczy, że kadra przywiązuje dużą wagę do utrzymania odpowiedniego ładu i porządku w Ośrodku oraz przestrzegania przez wychowanków dyscypliny. Oznacza to, że kadra dba o prawidłową organizację i właściwe funkcjonowanie Ośrodka, co może się przejawiać w dużej koncentracji na takich zewnętrznych aspektach, jak: porządek w pokojach wychowanków i innych pomieszczeniach Ośrodka, dbałość o teren przyległy do ośrodka itp. Kadra również może dość mocno zwracać uwagę na przygotowanie i realizację planu dnia, ale już mniej na jakość podejmowanych działań. Wychowankowie w tej kwestii mają odmienne zdanie. 
W podskali „Jasność/Klarowność” kadra uważa, że wychowankowie $\mathrm{w}$ odpowiednim stopniu znają zasady i procedury obowiązujące w MOW. Są również zaznajomieni z planem dnia, którego przestrzegają. Natomiast wychowankowie uważają, że formalne wymagania wynikające $\mathrm{z}$ regulaminów są dla nich niejasne i mało zrozumiałe.

W podskali „Kontrola personelu” wyniki uzyskane przez kadrę zatrudnioną w MOW i wychowanków nie różnią się w sposób istotny. Oznacza to, że opinie kadry i wychowanków, dotyczące pełnienia przez kadrę funkcji kontrolno-opiekuńczych, są zbliżone.

Jak wynika $z$ analizy powyższych podskal tworzących wymiar System organizacyjny instytucji, klimat społeczny MOW w zakresie dwóch pierwszych podskal nie kształtuje się prawidłowo, co oznacza, że kadra zatrudniona w MOW koncentruje się na strukturalnych i funkcjonalnych aspektach działalności Ośrodka.

W ramach analizy wyników badań dotyczących klimatu społecznego MOW dokonano zestawienia rangowego wyborów wychowanków i kadry zatrudnionej w Ośrodkach w ramach poszczególnych podskal (Tabela 4).

Tylko w podskali „Porządek i organizacja” wychowankowie oraz kadra byli zgodni. W pozostałych ośmiu podskalach wychowankowie i kadra dokonali innej oceny. Największa rozbieżność wystąpiła w podskali „Kontrola personelu” i podskali „Orientacja praktyczna”. Natomiast w przypadku podskali „Zaangażowanie” i podskali „Wsparcie” nastąpiło odwrócenie - wychowankowie ocenili podskalę „Zaangażowanie” jako najważniejszą (1 ranga), a podskalę „Wsparcie” jako drugą, kadra dokonała natomiast odwrotnego uszeregowania.

Tabela 4. Porównanie rang wyborów poszczególnych podskal dokonanych przez wychowanków i kadrę MOW

\begin{tabular}{|c|l|c|c|c|c|}
\hline \multirow{2}{*}{ Wymiar } & \multirow{2}{*}{ Podskale } & \multicolumn{2}{|c|}{$\begin{array}{c}\text { Wychowankowie } \\
\text { (N=616) }\end{array}$} & \multicolumn{2}{|c|}{$\begin{array}{c}\text { Kadra } \\
(\mathbf{N}=230)\end{array}$} \\
\cline { 3 - 6 } & & średnia & ranga* & średnia & ranga* \\
\hline \multirow{3}{*}{ Relacje interpersonalne } & Zaangażowanie & 6,662 & $\mathbf{1}$ & 8,317 & $\mathbf{2}$ \\
\cline { 2 - 6 } & Wsparcie & 6,649 & $\mathbf{2}$ & 8,822 & 1 \\
\cline { 2 - 6 } & Ekspresja & 4,774 & $\mathbf{9}$ & 6,052 & $\mathbf{8}$ \\
\hline
\end{tabular}




\begin{tabular}{|c|c|c|c|c|c|}
\hline \multirow{2}{*}{ Wymiar } & \multirow{2}{*}{ Podskale } & \multicolumn{2}{|c|}{$\begin{array}{c}\text { Wychowankowie } \\
(\mathrm{N}=616)\end{array}$} & \multicolumn{2}{|c|}{$\begin{array}{c}\text { Kadra } \\
(\mathrm{N}=\mathbf{2 3 0})\end{array}$} \\
\hline & & średnia & ranga* & średnia & ranga* \\
\hline \multirow{3}{*}{ Rozwój osobisty } & Autonomia & 5,727 & 6 & 6,491 & 7 \\
\hline & $\begin{array}{l}\text { Orientacja } \\
\text { praktyczna }\end{array}$ & 5,657 & 8 & 7,904 & 4 \\
\hline & $\begin{array}{l}\text { Orientacia } \\
\text { na problemy } \\
\text { osobiste }\end{array}$ & 5,703 & 7 & 7,670 & 5 \\
\hline \multirow{3}{*}{ System organizacyiny } & $\begin{array}{l}\text { Porzqdek } \\
\text { i organizacja }\end{array}$ & 6,531 & 3 & 8,000 & 3 \\
\hline & $\begin{array}{l}\text { Jasność/ } \\
\text { Klarowność }\end{array}$ & 6,013 & 4 & 6,957 & 6 \\
\hline & $\begin{array}{l}\text { Kontrola } \\
\text { personelu }\end{array}$ & 5,880 & 5 & 5,957 & 9 \\
\hline
\end{tabular}

*Ranga dla średniej od największej do najmniejszej (rozłącznie dla wychowanków i kadry). Źródło: badania własne.

WTabeli 5 przedstawiono porównanie wyników uzyskanych przez wychowanków MOW oraz kadrę w zakresie poszczególnych wymiarów klimatu społecznego.

Tabela 5. Porównanie wyników w zakresie wymiarów tworzqcych klimat społeczny MOW uzyskanych przez wychowanków i kadrę

\begin{tabular}{|l|c|c|c|c|c|}
\hline \multirow{2}{*}{ Wymiar } & \multicolumn{2}{|c|}{ Wychowankowie (N=616) } & \multicolumn{2}{c|}{ Kadra (N=230) } & \multirow{2}{*}{$\begin{array}{c}\text { p w teście } \\
\text { t-Studenta }\end{array}$} \\
\cline { 2 - 5 } & $\bar{\chi}$ & SD & $\bar{\chi}$ & SD & \\
\hline Relacje interpersonalne & 18,09 & 5,443 & 23,19 & 3,501 & $<0,0005$ \\
\hline Rozwój osobisty & 17,09 & 4,259 & 22,07 & 2,392 & $<0,0005$ \\
\hline System organizacyiny & 18,42 & 3,416 & 20,91 & 2,548 & $<0,0005$ \\
\hline
\end{tabular}

Źródło: badania własne.

Różnica w średnich, uzyskana dla wymiaru Relacje interpersonalne, może sugerować, że relacje interpersonalne pomiędzy wychowankami a kadrą nie kształtują się prawidłowo. Kadra bardziej 
optymistycznie ocenia te relacje niż wychowankowie. Jednak deklaracja ze strony kadry, iż relacje interpersonalne $z$ wychowankami są dla niej ważne, może wynikać zazwyczaj z chęci udzielenia poprawnej odpowiedzi oraz $\mathrm{z}$ faktu, że zgodnie z koncepcjami resocjalizacyjnymi tak należy postępować.

Największe rozbieżności powstały w ocenie dotyczącej wymiaru Rozwój osobisty. Wychowankowie uważają, że kadra zatrudniona w MOW w małym stopniu koncentruje się na ich problemach praktycznych związanych z nauką czy też problemach osobistych oraz przygotowaniem ich do opuszczenia Ośrodka. Kadra małą wagę przywiązuje do rozwijania u wychowanków takich umiejętności, jak: autonomia, niezależność i samodzielność, które są bardzo istotne ze względu na funkcjonowanie społeczne jednostki. Wychowankowie, w związku z ogromnymi zaległościami w nauce szkolnej, opuszczając Ośrodek, często są na etapie ukończenia gimnazjum. Jest to bardzo niekorzystna sytuacja, gdyż wychowanek po opuszczeniu Ośrodka nie może podjąć pracy zarobkowej i nie może samodzielnie się utrzymać. W wyniku takiej sytuacji wychowanek może się stać podopiecznym instytucji pomocowych, wchodzić w konflikt z prawem, a przez to być zagrożony wykluczeniem społecznym.

W zakresie wymiaru System organizacyjny wynika, że kadra bardzo mocno skoncentrowana jest na prawidłowym funkcjonowaniu systemu organizacyjnego Ośrodka, szczególnie w aspekcie strukturalnym i formalnym. Kadra w dużej mierze dba o utrzymanie porządku i dobrej organizacji Ośrodka oraz przestrzeganie przez wychowanków obowiązujących zasad i regulaminów. Wychowankowie zaś w mniejszym stopniu znają zasady i procedury obowiązujące w MOW. Często nawet jeśli je znają, to są one dla nich niejasne i mało zrozumiałe. Może to świadczyć o braku odpowiedniego informowania wychowanków przez kadrę o celowości wprowadzanych regulaminów, praw i obowiązków. W Ośrodkach dość często nie ma samorządu wychowanków (lub funkcjonuje on tylko „na papierze”), który mógłby w realny sposób uczestniczyć w tworzeniu zasad panujących w tych placówkach.

W wyniku szczegółowej analizy, która wykazała istotne rozbieżności w opinii wychowanków i kadry na temat klimatu społecznego, można stwierdzić, że dominującym klimatem młodzieżowych ośrodków wychowawczych w Polsce jest klimat kontrolująco-restrykcyjny. Oznacza to, że kadra mały nacisk kładzie na 
prawidłowy przebieg relacji interpersonalnych, okazuje mniej wsparcia wychowankom. W mniejszym stopniu nastawiona jest na zaspokojenie potrzeb wychowanków oraz przygotowanie ich do opuszczenia Ośrodka. Kadra najbardziej koncentruje się na przestrzeganiu ładu i porządku oraz dyscypliny.

Należy jednak wskazać, że opinie kadry zatrudnionej w MOW są bardziej optymistyczne niż wychowanków przebywających w Ośrodkach. Zestawienie rangowe (Tabela 6) pozwala na porównanie wyborów poszczególnych wymiarów dokonanych przez wychowanków i kadrę.

Tabela 6. Porównanie rang wyborów poszczególnych wymiarów klimatu społecznego dokonanych przez wychowanków i kadrę MOW

\begin{tabular}{|l|c|c|c|c|}
\hline \multirow{2}{*}{ Wymiar } & \multicolumn{2}{|c|}{$\begin{array}{c}\text { Wychowankowie } \\
\text { (N=616) }\end{array}$} & \multicolumn{2}{c|}{$\begin{array}{c}\text { Kadra } \\
\text { (N=230) }\end{array}$} \\
\cline { 2 - 5 } & średnia & ranga* & średnia & ranga* \\
\hline Relacje interpersonalne & 18,086 & 2 & 23,191 & 1 \\
\hline Rozwój osobisty & 17,088 & 3 & 22,065 & 2 \\
\hline System organizacyiny & 18,424 & 1 & 20,913 & 3 \\
\hline
\end{tabular}

*Ranga dla średniej od największej do najmniejszej (rozłącznie dla wychowanków i kadry). Źródło: badania własne.

Wychowankowie uważają, że w Ośrodkach przede wszystkim zwraca się dużą uwagę na aspekty związane z systemem organizacyjnym, czyli na porządek i organizację oraz kontrolę. Mniej natomiast uwagi poświęca się na relacje interpersonalne. Zdecydowanie, w opinii wychowanków, zaniedbuje się w Ośrodkach te elementy klimatu, które związane są z kreowaniem środowiska terapeutycznego, czyli które wpływają na ich autonomię oraz rozwój. Biorąc tylko pod uwagę dokonaną przez wychowanków ocenę klimatu społecznego Ośrodków, można dojść do przekonania, że w Ośrodkach występuje klimat kontrolująco-restrykcyjny.

Kadra MOW uważa, że w Ośrodkach w największym stopniu dba się o relacje interpersonalne, jakie panują wśród wychowanków oraz między kadrą a wychowankami. Również zwraca się uwagę na autonomię wychowanków, ich edukację i przygotowanie do opuszczenia 
Ośrodka. Kadra najmniejszą wagę przywiązuje do utrzymania porządku i dyscypliny w MOW oraz kontroli wychowanków. Biorąc tylko pod uwagę opinię kadry dotyczącą klimatu społecznego Ośrodków, można dojąć do przekonania, że w MOW kształtuje się klimat terapeutyczno-wychowawczy.

Przeprowadzone przez innych autorów badania potwierdzają $a^{33}$, że w polskich placówkach resocjalizacyjnych dla nieletnich przeważa kontrolująco-restrykcyjny klimat.

\section{Wnioski z badań}

Z przeprowadzonej analizy badań wynika, że dominującym klimatem młodzieżowych ośrodków wychowawczych jest klimat kontrolująco-restrykcyjny. Należy podkreślić, że ocena klimatu społecznego w zakresie wymiarów: Relacje interpersonalne, Rozwój osobisty oraz System organizacyjny, dokonana przez wychowanków przebywających w Ośrodku i kadrę zatrudnioną w MOW, różniła się w sposób istotny statystycznie. Kadra dokonywała bardziej optymistycznej oceny niż wychowankowie, co oznacza, że obie te grupy zupełnie inaczej postrzegają klimat społeczny Ośrodków.

Analizując oddzielnie opinie wychowanków i kadry dotyczące oceny klimatu społecznego Ośrodków, można zauważyć, że występują tu istotne rozbieżności. W ocenie wychowanków w Ośrodkach dominuje klimat kontrolująco-restrykcyjny, zaś zdaniem kadry terapeutyczno-wychowawczy. Rozbieżności w ocenie świadczą o nieprawidłowym kształtowaniu się klimatu społecznego, co utrudnia przebieg właściwego procesu wychowania i resocjalizacji. Najczęściej wychowankowie pobyt w MOW odbierają jako ograniczenie (czy nawet pozbawienie) wolności, zaś kadra koncentruje się w dużej mierze na aspektach formalnych wykonywanej pracy, w szczególności dbaniu o utrzymanie porządku i dobrej organizacji Ośrodka oraz na egzekwowaniu od wychowanków przestrzegania dyscypliny, czyli prawidłowej adaptacji podopiecznych do roli wychowanków.

33 Por.: P. Frąckowiak, Kierunki rozwoju resocjalizacji w polskich zaktadach dla nieletnich, Poznań - Środa Wielkopolska 2006; S. Sobczak, Klimat spoteczny instytucji resocjalizujacych, „Pedagogika Społeczna” 2007, nr 3, s. 133-152; A. Skuza, Klimat spoteczny polskiego zaktadu poprawczego (pedagogiczna analiza czynników kreujacych) (Praca doktorska, Kielce 2011). 
Jean Pinatel i Anne-Marie Favard ${ }^{34}$ twierdzą, że im lepiej wychowanek jest przystosowany do środowiska wychowawczego instytucji, tym gorzej po jej opuszczeniu przystosowuje się do środowiska zewnętrznego (tym gorzej, im dłużej przebywał w tej instytucji). W Ośrodkach wychowanek jest „obsługiwany” i ma mały wpływ na podejmowanie decyzji dotyczących jego funkcjonowania (co wykazały badania). Jak wskazuje Maciej Muskała, w placówkach resocjalizacyjnych ma miejsce nieuchronność prizonizacji lub resocjalizacji pozornej ${ }^{35}$, a także możliwość wystąpienia u wychowanków wyuczonej bezradności ${ }^{36}$. Mechanizm wyuczonej bezradności może się również uruchomić po opuszczeniu placówki. W warunkach pozainstytucjonalnych wychowanek staje się bezradny, gdyż wyuczone zachowania utrudniają mu odnalezienie się w innych, często nowych sytuacjach, np. związanych z właściwym realizowaniem ról społecznych (m.in. pracownika). Wychowanek, który opuszcza Ośrodek, nie zostaje objęty opieką następczą (zasada continuous care - por. Rekomendacja Rady Europy ${ }^{37}$ ), ponadto nie może liczyć na wsparcie swojej rodziny, a często nie wie też jak skorzystać ze wsparcia oferowanego przez wyspecjalizowane instytucje.

W młodzieżowych ośrodkach wychowawczych, tak jak i w innych instytucjach totalnych ${ }^{38}$, aktywność wychowanków jest ściśle wyznaczana obowiązującymi przepisami, a relacje pomiędzy kadrą a wychowankami oparte są na negatywnych stereotypach odzwierciedlonych dość często w postawie konfrontacyjnej reprezentowanej przez wychowanków, szczególnie w momencie przybycia do placówki3 ${ }^{39}$. W związku z tym, że wychowankowie nie mogą w sposób jawny wypowiadać

34 Por. L. Pytka, Pedagogika resocjalizacyjna. Wybrane zagadnienia teoretyczne, diagnostyczne i metodyczne, dz. cyt., s. 131.

35 Por. M. Muskała, System resocjalizacyjny Glen Mills School, „Problemy Opiekuńczo-Wychowawcze" 2008, nr 1, s. 35.

36 Por. M. Seligman, Optymizmu można się nauczyć. Jak zmienić swoje myślenie i swoje życie, dz. cyt.

37 Recommendation (2003)20 concerning new ways of dealing with juvenile delinquency and the role of juvenile justice (2003), <http://www. coe.int/t/dghl/standardsetting/prisons/PCCP\%20documents\%202013/ Rec(2003)20_E.pdf> [dostęp: 15.10.2017].

38 Por. E. Goffman, Instytucje totalne, przeł. J. Łaszcz, Sopot 2011.

39 Por. P. Chomczyński, Problem dominacji i podporzqdkowania wśród dziewczat i chtopców w Zaktadach Poprawczych typu pótotwartego w Polsce, <http://repozytorium.uni.lodz.pl:8080/xmlui/handle/11089/1083> [dostęp: 15.10.2017]. 
swoich opinii na temat placówki oraz ujawniać swoich różnorodnych emocji, tworzy się podkultura („drugie życie”), za pomocą której manifestują oni swój protest wobec pozbawienia ich prywatności i regulowania wszelkiej aktywności. Przystąpienie do nieformalnej grupy jest niekiedy jedyną samodzielną, ważną decyzją podejmowaną przez wychowanków ${ }^{40}$.

Zdaniem Marka Konopczyńskiego ${ }^{41}$, podejmowane działania mają na celu przystosowanie i adaptację wychowanków do pobytu w placówce poprzez przymuszanie ich do przestrzegania reguł regulaminowych i organizacyjnych.

Konsekwencją umieszczenia wychowanka w Ośrodku jest też uruchomienie mechanizmu stygmatyzacji. Aby poradzić sobie ze społecznym naznaczeniem, wychowankowie przyjmują określone style adaptacji instytucjonalnej, które pełnią funkcję redukcji napięcia motywacyjnego wynikającego $\mathrm{z}$ wewnętrznej atrybucji naznaczenia i przypisania sobie atrybutów piętna ${ }^{42}$.

Wychowankowie MOW, zwłaszcza jeśli mają za sobą doświadczenie wcześniejszego pobytu w innych placówkach resocjalizacyjnych i socjalizacyjnych (a prawie połowa osób badanych ma takie doświadczenie), nabywają umiejętności przystosowawcze, które pozwalają im na coraz szybsze i bardziej efektywne wejście w kulturę organizacyjną danej instytucji. Jak wskazuje Piotr Chomczyński,

[...] pomimo pewnych odmienności w zakresie norm, zwyczajów, wartości itd., które różnią poszczególne zakłady, istnieje pewna wspólna platforma przekonań, sposobów postępowania, które doświadczony wychowanek jest w stanie sobie przyswoić i wykorzystać w celu adaptacji do nowej placówki ${ }^{43}$.

40 Por. P. Chomczyński, Sposoby radzenia sobie z negatywnymi emocjami wśród wychowanków zaktadów poprawczych w Polsce, <http://repozytorium.uni. lodz.pl:8080/xmlui/handle/11089/1055> [dostęp: 15.10.2017].

41 Por. M. Konopczyński, Kryzys resocjalizacji, czy(li) sukces dziatań pozornych. Refleksje wokót polskiej rzeczywistości resocjalizacyjnej, Warszawa 2013, s. 154.

42 Por. M. Gawęcka, Transpozycja wychowania instytucjonalnego w świetle analizy porównawczej instytucji totalnej $i$ symbolicznej, w: Opieka $i$ wychowanie w instytucjach wparcia spotecznego. Diagnoza i kierunki rozwoju, red. R. Szczepanik, J. Wawrzyniak, Łódź 2012, s. 25-26.

43 P. Chomczyński, Sposoby radzenia sobie z negatywnymi emocjami wśród wychowanków zaktadów poprawczych w Polsce, <http://repozytorium.uni.lodz. pl:8080/xmlui/handle/11089/1055> [dostęp: 15.10.2017]. 
W ten sposób wychowanek łatwo zaczyna wchodzić w rolę „wychowanka Ośrodka" oraz bardzo szybko zaczyna się z nią identyfikować i przez jej pryzmat spostrzegać siebie. Kadra zatrudniona w Ośrodkach często pogłębia przyjmowanie przez wychowanków takiej roli (aczkolwiek w udzielanych wywiadach pedagodzy i psychologowie temu zaprzeczyli). Nacisk kadry na nauczenie się przez wychowanka okazywania negatywnych emocji w sposób akceptowany jest jednym z priorytetowych działań placówki, stojących wyżej niż np. polityka edukacyjna. Według Marka Konopczyńskiego ${ }^{44}$ kadra instytucji resocjalizacyjnych traktuje zafałszowane przystosowanie wychowanków jako trwałą pozytywną zmianę, będącą efektem procesu wychowania resocjalizacyjnego. Celem procesu resocjalizacji nie jest wykreowanie z podopiecznego „wychowanka Ośrodka”, który potrafi przestrzegać zasad i regulaminów, ale końcowym etapem resocjalizacji ma być akceptacja środowiskowa wychowanka, czyli akceptacja przez otoczenie jego społecznych i kulturowych form i sposobów rozwiązywania problemów.

$\mathrm{W}$ istniejącym w Polsce systemie instytucjonalno-prawnym młodzieżowe ośrodki wychowawcze w zasadzie nie mają możliwości właściwego modyfikowania tożsamości nieletnich. Przeprowadzone badania, dotyczące klimatu społecznego tych Ośrodków, utwierdzają nas jeszcze bardziej w tym przekonaniu, że Ośrodki te mają głównie charakter dyscyplinarno-karny.

\section{Bibliografia}

Adrjan B., Klimat szkoty, w: Encyklopedia pedagogiczna XXI wieku, t. 2, red. T. Pilch, Wydawnictwo Akademickie „Żak”, Warszawa 2008.

Bratnicki M., Wyciślak M., Klimat organizacyjny:pojęcie, mierzenie, badania i diagnoza, „Prakseologia” 1980, nr 4(76), s. 85-103.

Chomczyński P., Problem dominacji i podporzadkowania wśród dziewczat i chtopców w Zaktadach Poprawczych typu pótotwartego w Polsce, <http:// repozytorium.uni.lodz.pl:8080/xmlui/handle/11089/1083>.

Chomczyński P., Sposoby radzenia sobie z negatywnymi emocjami wśród wychowanków zaktadów poprawczych w Polsce, <http://repozytorium.uni. lodz.pl:8080/xmlui/handle/11089/1055>.

44 Por. M. Konopczyński, Kryzys resocjalizacji, czy(li) sukces dziatań pozornych. Refleksje wokót polskiej rzeczywistości resocjalizacyjnej, dz. cyt., s. 221. 
Frąckowiak P., Kierunki rozwoju resocjalizacji w polskich zaktadach dla nieletnich, Garmond. Oficyna Wydawnicza, Poznań - Środa Wielkopolska 2006.

Gawęcka M., Transpozycja wychowania instytucjonalnego w świetle analizy porównawczej instytucji totalnej $i$ symbolicznej, w: Opieka $i$ wychowanie w instytucjach wparcia spotecznego. Diagnoza i kierunki rozwoju, red. R. Szczepanik, J. Wawrzyniak, Wydawnictwo AHE, Łódź 2012.

Goffman E., Instytucje totalne, przeł. J. Easzcz, GWP, Sopot 2011.

Hoy W.K., Hanuum J.W., Middle School Climate: An Empirical Assessment of Organizational Health and Student Achievement, „Educational Administration Quarterly"1997, t. 33, nr 3, s. 290-301.

Konopczyński M., Teoretyczne podstawy metodyki kulturotechnicznych oddziatywań resocjalizacyjnych wobec nieletnich. Zarys koncepcji twórczej resocjalizacji, Wydawnictwo Naukowe PWN, Warszawa 2006.

Konopczyński M., Kryzys resocjalizacji czy(li) sukces dziatań pozornych. Refleksje wokót polskiej rzeczywistości resocjalizacyjnej, Pedagogium. Wyższa Szkoła Nauk Społecznych, Warszawa 2013.

Kuć M., Prawne podstawy resocjalizacji, Wydawnictwo C.H. Beck, Warszawa 2011.

Lewin K., Field theory in social science: Selected theoretical papers, Harper \& Brothers, Washington 1951.

Moos R.H., Correctional Institutions Environment Scale: Sampler Set, Mind Garden Inc., Menlo Park (CA) 1974.

Moos R.H., Evaluating correctional and community settings, John Wiley \& Sons, New York - London - Sydney - Toronto 1975.

Moos R.H., The Social Climate Scales: A User's Guide, Mind Garden Inc., Menlo Park (CA) 1994.

Muskała M., System resocjalizacyjny Glen Mills School, „Problemy Opiekunczo-Wychowawcze" 2008, nr 1, s. 30-35.

Pufal-Struzik I., Atmosfera i klimat organizacji jako czynniki stymulujace lub hamujace efektywnośc twórczych zachowań pracowników, w: Myśl psychologiczna w Polsce Odrodzonej, red. A. Bańka, R. Derbis, Gemini, Poznań 1993.

Pytka L., Pedagogika resocjalizacyjna. Wybrane zagadnienia teoretyczne, diagnostyczne $i$ metodyczne, Wydawnictwo Akademii Pedagogiki Specjalnej im. M. Grzegorzewskiej, Warszawa 2005.

Recommendation (2003)20 concerning new ways of dealing with juvenile delinquency and the role of juvenile justice (2003), <http://www. coe.int/t/dghl/standardsetting/prisons/PCCP\%20documents\%202013/ $\operatorname{Rec}(2003) 20 \_E . p d f>$.

Rozporządzenie Ministra Edukacji Narodowej z dnia 2 listopada 2015 roku w sprawie rodzajów i szczegółowych zasad działania placówek publicznych, warunków pobytu dzieci i młodzieży w tych placówkach oraz wysokości i zasad odpłatności wnoszonej przez rodziców za pobyt ich dzieci w tych placówkach (Dz.U. z 2015 r. Nr 0, poz. 1872). 
Seligman M., Optymizmu można się nauczyć. Jak zmienić swoje myślenie i swoje życie, przeł. A. Jankowski, Media Rodzina, Poznań 2007.

Siemionow J., Efektywność oddziatywań instytucji resocjalizacyjnych a nowe trendy w resocjalizacji, w: Wspótczesne kierunki zmian w teorii i praktyce resocjalizacyjnej, red. M. Konopczyński, W. Ambrozik, Centrum Metodyczne Pomocy Psychologiczno-Pedagogicznej, Warszawa 2009.

Skuza A., Klimat spoteczny polskiego zaktadu poprawczego (pedagogiczna analiza czynników kreujacych), (Praca doktorska, Kielce 2011).

Sobczak S., Klimat spoteczny instytucji resocjalizujących, „Pedagogika Społeczna” 2007, nr 3, s. 133-152.

Tatarowicz J., Klimat spoteczny szkoty - zdrowy czy chory?, w: Zanim w szkole będzie źle... Profilaktyka zagrożeń, red. K. Ostrowska, J. Tatarowicz, Centrum Metodyczne Pomocy Psychologiczno-Pedagogicznej MEN, Warszawa 1996.

\section{ADRES DO KORESPONDENCJI:}

Dr Magdalena Staniaszek

Uniwersytet Łódzki

Wydział Nauk o Wychowaniu

e-mail: magdalena.staniaszek@uni.lodz.pl 